\title{
Archons, Protons and Tectons: an update
}

Janse, A.J.A.

Archon Exploration Pty Ltd, 11 Rowsley Way, Carine, Western Australia 6020

Janse (1994) proposed a simple classification of cratons into three major divisions, i.e. Archons, Protons and Tectons. Cratons were interpreted in the broadest sense in that they include Archaean cores or nuclei as well as Palaeoproterozoic, Mesoproterozoic and Neoproterozoic mobile belts. This whole assemblage often carries a bewildering array of local stratigraphic and tectonic names so that it is confusing for a geologist, not familiar with the area, to understand the tectonic pattern. This is important for diamond exploration as economic kimberlites occur only in areas underlain by Archaean basement, termed Archons, which in most cases infers a thick lithosphere, whereas economic lamproites can occur in areas underlain by Palaeoproterozoic basement, termed Protons (Janse, 1994). The divisions were defined as follows:

i) Archon - basement rocks of Archaean age and the minimum age of the last thermal event I is 2,500 Ma;

ii) Proton - basement rocks of Palaeoproterozoic to Mesozoic age, 2,500 - 1,600 Ma and the minimum age of the last thermal event is $1,600 \mathrm{Ma}$;

iii) Tecton - basement rocks of Neoproterozoic age, 1,600 - $800 \mathrm{Ma}$ and the last thermal event is $800 \mathrm{Ma}$.

Parts of a craton can be re-activated by a later thermal event and so become rejuvenated from Archon to Proton or Tecton or from Proton to Tecton and this has consequences for their economic diamond potential.

The three-fold division has generally been accepted favourably and has been referred to in many publications. Most critics said that the tectonic framework of cratons was not that simple and that the basement of Protons should be differentiated into reworked Archaean and juvenile Proterozoic; others suggested a further division into old and young Protons with time boundaries at 2,500 to $1,800 \mathrm{Ma}$ and 1,800 to $1,000 \mathrm{Ma}$, shifting the Tecton boundary to 1,000 to $600 \mathrm{Ma}$. Indeed, the tectonic frameworks of cratons are often very complex and it was exactly for this reason that a simple division was proposed knowing that it only approximated the structure of the actual tectonic framework. Griffin et al (1997) found that mineral chemistry data from mantle xenoliths corroborated a three-fold division with the 1,600 MA boundary shifted to 1,000 Ma.

On-going tectonic research worldwide will undoubtedly keep changing the picture but for the moment a four-fold division is proposed. It is difficult to find four simple names, instead of three, so that a preliminary new proposal includes the following:

i) Archon - age of basement rocks to $2,500 \mathrm{Ma}$;

ii) Palaeoproton - age of basement from 2,500 to $1,800 \mathrm{Ma}$;

iii) Mesoproton - age of basement from 1,800 to 1,000 Ma;

iv) Tecton - age of basement from 1,000 to $600 \mathrm{Ma}$.

Compared to the maps displayed in Janse (1994), the geographical boundaries of the worldwide cratonic subdivisions have been redrawn in places (as shown in the posters) to accommodate the new divisions. New information has indicated that blocks of probable Archaean basement occur in several new areas which was not generally known before, and new kimberlite and lamproite fields, some of which contain economic occurrences, have been discovered since 1991 (the date of the maps in Janse, 1994). New discoveries and changes are briefly summarized below.

Australia. The Australian continent comprises three cratons, the North Australian, West Australian and South Australian cratons in the western three-quarters of the continent. The North Australian 
craton contains the Argyle olivine lamproite occurrence on which the world's largest diamond mine was developed. It also contains the new Merlin kimberlite field, which was discovered by Ashton Mining in 1994. It contains 12 small pipes, of which 4 pipes are being developed into a diamond mine with a planned annual production of 300,000 carats starting in early 1999. Diamondiferous kimberlites were also known from the northern part of the Kimberley Archon and it appears that the new Beta Creek kimberlite field, discovered in 1994 by Striker Resources contains an economic occurrence in the Lower Bulgurri and Ashmore dykes and pipes. The North Australian craton produces up to $40 \%$ by weight and $5 \%$ by value of the world's diamond production at present and ranks No. 1 in weight and No. 4 in value. The new Leonora kimberlite field has been found recently (1997) in the central part of the Yilgarn Archon of the West Australian craton. Six occurrences are known so far. A few contain traces of diamonds, but no economic occurrences have been outlined to date. The Nabberu kimberlite field in the northeastern part of the Yilgarn Archon was discovered in 1990, but no economic discoveries were made. Both fields are Palaeoproterozoic in age. A few lamprophyric occurrences, superficially resembling kimberlites were found on the Pilbara Archon of the West Australian craton in 1991, but apparently no true kimberlites have been found there. The West Australian craton is one of the few of the world's cratons in which true kimberlites were not known for and have been discovered only recently. Several kimberlite fields, some of which contain diamondiferous kimberlites, are known in the South Australian craton on the Gawler Archon and the Adelaide Proton, but no economic discoveries have been made. The non-cratonic eastern part of the Australian continent, the Tasman Orogen, contains numerous small, alluvial diamond occurrences. The primary source rock of these diamonds has not yet been found. A possible relationship with sapphire-bearing alkaline basalts and a new concept of diamond formation during Palaeozoic subduction of ocean floor basalt and sediments (the S-model) has been proposed (Barron et al, 1996).

China. There have been more discoveries of kimberlites and lamproites, some of which contain diamonds, in the North China craton and the Yangtze craton, but this has not resulted in a significant increase in diamond production. Unconfirmed reports of the discovery of kimberlites in southern North Korea and perhaps the northern part of South Korea exist, but no specific data are available.

India. The Geological Survey of India has reported the discovery of additional kimberlites in the Dharwar Archon, including some in southern Madhya Pradesh which may be the source of the alluvial diamonds found in Orissa. However, no economic discoveries have been made as yet. Since 1994 the Mining Act has been changed to allow foreign companies to explore in India so more discoveries may be made in future.

Southern Africa. Additional discoveries of small diamondiferous kimberlite pipes and dykes has increased the already high number of occurrences in the Southern African craton. In particular the Klipspringer dykes, being evaluated by SouthernEra, may become a mine. The opening of the Venetia mine and increased production at the Orapa and Jwaneng mines made a considerable impact on diamond production. The southern African craton produces at least $25 \%$ by weight and $43 \%$ by value of the world's production by volume, and ranks No. 2 in weight and No. 1 in value.

Central Africa. Two of the three Archons in the Central African craton contain economic kimberlite pipes, but these have not yet been found in the Gabon Archon. The Williamson mine in the Tanzanian Archon has been refitted by Willcroft (a De Beers affiliated company) with the Tanzanian government stepping back from $50 \%$ to $25 \%$ equity, but production is not expected to be high. Several pipes in the Lunda-Kasai Archon located in Angola are believed to be economic, but the Angolan civil war prevented their development. One pipe, Catoca, is reported to be close to start-up. Plans for the development of another pipe, Camafuca-Camazambo are being considered. Thus far all production in the Central African craton came from alluvial deposits. Since 1990 this production has decreased dramatically because of political and social unrest, but may pick up as the 
situation appears to have quieted down. The Central African craton produces $23 \%$ by weight and 24 $\%$ by value in the world's diamond production and ranks No. 3 in weight and No. 2 in value.

West Africa. Despite reports to the contrary I do not think that the primary source for the alluvial diamonds in Ghana has been found. The civil wars in Liberia and Sierra Leone have prevented development of known pipes and dykes and decreased alluvial production. The Aredor mine in Guinea closed for economic reasons, but exploration and re-development are being considered. The Kenieba field in Mali is being re-evaluated by Ashton Mining who is also exploring the Reguibat shield in northern Mauretania. The West African craton produces $2 \%$ by weight and $3 \%$ by value in the world's diamond production and ranks No. 6 in weight and No. 5 in value.

North America. The discovery of economic kimberlites in the Slave Archon of the Laurentian craton has rejuvenated diamond exploration efforts worldwide. Since 1991, more than 150 kimberlites were found there, of which more than 50 are diamond-bearing. The youngest age of intrusion is Eocene (47.5 Ma). Other kimberlites in the region are of Late Ordovician age (440-450 Ma). The BHP-DiaMet mine, located between Exeter Lake and Lac de Gras is scheduled to start production in 1998 at an annual rate of 2 to 3 million carats. Diamond-bearing kimberlites of Mesozoic and of Precambrian (1100 Ma) age have been found in the James Bay Lowlands of Ontario, but have not yet proved to be economic. Detailed evaluation of the long-known Crater of Diamonds in Arkansas has shown that this occurrence is not economic.

South America. The South American continent comprises two cratons, the Amazonian craton, which includes the Guiana, Xingu and São Francisco Archons separated by several Proterozoic belts, and the Plata craton in Uruguay and northern Argentina, the boundaries of which are still undefined. Despite renewed exploration, which found additional kimberlites and lamproites, the source of the alluvial diamonds on the southwestern margin of the São Francisco Archon in the Coromandel region (Alto Parnaíba region) of southwestern Minas Gerais and eastern Goaís has still not yet been found. All production from the Amazonian craton comes from alluvial deposits. It produces about $3 \%$ by weight and $3 \%$ by value in the world's diamond production and ranks No. 5 in weight and No. 6 in value. There is no recorded diamond production from the Plata craton.

Russia. The Russian Federated State comprises two cratons, the East Siberian craton and the Amur craton and shares a third, the East European craton, with the Ukraine. From the seven pipes operating in 1990 only one, Udachnaya, appears to be still in continuous production; the rest being delayed in refitting owing to lack of finance. As a result production decreased markedly. The Jubilee pipe in the Daaldyn field has been scheduled for start up in the near future. The Nyurba diamondiferous kimberlite field has recently been discovered near the confluence of the $\mathrm{xxx}$ and the Vilyiu River in the Tyung Archon of the East Siberian craton. This may revive diamond production in the east Siberian craton which still produces $11 \%$ by weight and $21 \%$ by value in the world's diamond production and ranks No. 4 in weight and No. 3 in value.

\section{References:}

Barron, L.M., Lishmund, S.R., Oakes, G.M., Barron, B.J. and Sutherland, F.L., 1996, Subduction model for the origin of some diamonds in the Palaeozoic of eastern New South Wales: Aust. J. Earth Sc., 43, p. 257-267.

Griffin, W.J., O’Reilly, S.Y., Ryan, C.G., Gaul, O. and Ionov, D.A., 1998, Secular variation in the composition of subcontinental lithospheric mantle: In J. Braun, J. C. Dooley, B. R. Goleby, R. D. van der Hilst and C. T.Klootwijk (eds) Structure \& Evolution of the Australian Continent, Geodynamics Volume 26, Amer. Geopyhys. Union, Washington D.C., p. 1-26.

Janse, A.J.A., 1994, Is Clifford's Rule still valid? Affirmative examples from around the world: In H.O.A. Meyer and O.H. Leonardos (eds) Proceedings of the Fifth International Kimberlite conference 2, Diamonds: Characterization, Genesis and Exploration. Brasília: CPRM Special Publication 1B, p. 215-235. 